\title{
Wireline Log Petrophysical Characterization of Selected Reservoirs in Zeta field, Niger Delta, Nigeria
}

\author{
${ }^{1}$ Science Laboratory Technology Department, Ken Saro Wiwa Polytechnic, Bori, Nigeria \\ ${ }^{2}$ Physics Department, Rivers State University, Nkpolu-Oroworukwo, Rivers State, Nigeria \\ DOI: 10.29322/IJSRP.11.10.2021.p11812 \\ http://dx.doi.org/10.29322/IJSRP.11.10.2021.p11812
}

${ }^{1}$ P. S. Nwiyor, ${ }^{2}$ E. D. Uko, ${ }^{2}$ I. Tamunobereton-ari, ${ }^{2}$ A. R. C. Amakiri and ${ }^{2}$ O. A Davies

\begin{abstract}
This research was centered around making estimates of petrophysical measures in sandstone reservoirs in Zeta Field, Onshore Niger Delta. The petrophysical measures estimated were porosity, permeability, water and hydrocarbon saturation, volume of shale and net-to-gross variations. To this end, seven (7) well $\operatorname{logs}$ were analysed. The results of the analysis revealed the presence of 3 viable hydrocarbon-bearing sandstone reservoirs. Correlation of these sand bodies show that each of the sand units spreads through the field, varying in thickness and some units occurring at greater depth than their adjacent unit which is perhaps a sign of faulting. The thickness of each sand unit is highly variable, ranging between 82 and $350 \mathrm{ft}$. The fractional values of porosities within the three identified sandstone reservoir units ranged from 0.15 to 0.26 , with estimates of permeability between 89.92 to $2552.67 \mathrm{mD}$. From estimates made, the shale volume within the reservoirs of interest ranged from $7.5 \%$ to $55.88 \%$. The average estimates of fractional water saturation in the three reservoirs of interest ranged from 0.16 to 0.73 , with an estimated value of net-to ratio ranging from 0.17 to 0.96 for the reservoirs rocks of interest. This showed that the sandstones in the study area are viable hydrocarbon-bearing reservoir units, that could be profitable for further exploration activities.
\end{abstract}

Index Terms- Reservoir, Petrophysical, Hydrocarbon, Zeta Field

\section{INTRODUCTION}

$\mathrm{T}_{1}$ he evaluation and characterization of reservoir rocks relative to their porosity, water saturation and permeability determinations, enhances the ability to estimate hydrocarbon reserves and reservoir bed thickness, and to distinguish between gas, oil and water bearing strata, by observing their electrical resistivity and relative permeability value $[1,2]$. Petrophysical analysis is a fundamental part of any reservoir characterization work, particularly in differentiation between the hydrocarbon and non-hydrocarbon bearing zones [3]. Wireline logs are usually employed in petrophysical analysis of any oil bearing rock [4]. This is quite convenient as wireline logs provide a chance to define the composition, variability and physical properties of the rocks surrounding the well-bore, creating a scenario for understanding the subsurface at a relatively cheaper cost [3, 5]. Usually, petrophysical analysis of any oil field could encompass reservoir fluid properties and reservoir rock properties which could play major roles in how much oil recovery and production can be achieved in the field of interest [6]. In practice, petrophysical analysis is done to convert the wireline log data into reservoir properties such as volume of shale, porosity, permeability, water and hydrocarbon saturation. Appropriate examination of these reservoir properties can significantly boost the ability to discriminate between the hydrocarbon and non-hydrocarbon bearing zones $[7,8]$. Inaccurate characterization could lead to drilling dry holes, reserve over-estimation and inaccurate pore pressure prediction. This work is aimed at carrying out petrophysical characterization using well logs in Zeta Field situated in Greater Ughelli Depositional Belt of Niger Delta, Nigeria.

Richardson [8] utilizes a suite of borehole geophysical wire lines $\operatorname{logs}$ for the evaluation of the hydrocarbon potential of an oil field in Niger Delta. He showed that the reservoirs delineated in the study area have average porosity of $30.2 \%$, water saturation of $19.7 \%$ and hydrocarbon saturation of $80.3 \%$.

In their work, Eze et. al. [9] carried out a petrophysical analysis on a typical Niger Delta oil producing field. They did this by delineating reservoir units using available composite wireline log to determine geometric properties (porosity and permeability). They showed that the petrophysical characteristics of the reservoirs are good especially at the areas of interest (hydrocarbon zones).

Additionally, Edigbue et. al. [10] integrated 3D seismic and petrophysical data to evaluate hydrocarbon reservoir potentials of "Keke" field in the Niger Delta. Two sands units between $9127 \mathrm{ft}$ and $11152 \mathrm{ft}$ were correlated and mapped using gamma ray log while petrophysical parameters were obtained from other well logs. They discovered that the trapping mechanisms and the obtained Petrophysical parameters in "Keke" field are favorable for hydrocarbon accumulation.

\section{LOCATION AND GEOLOGICAL SETTING OF STUDY AREA}

The datasets (well logs) used for the study were acquired from "Zeta" field in Greater Ughelli Depositional Belt, Onshore Niger Delta field, Nigeria (Fig. 1). The field is located in Oil Mining Lease (OML) 58. The concession is situated Onshore, near Port Harcourt in Niger Delta, one of the world's largest hydrocarbon provinces $[11,12]$. The latitudinal and longitudinal extents of the Delta lie along the coordinates $4^{\circ} \mathrm{N}$ to $9^{\circ} \mathrm{N}$ and $4^{\circ} \mathrm{E}$ to $9^{\circ} \mathrm{E}$ [13]. Only one petroleum system has been identified to be associated to the Niger Delta basin and it is known as the (Akata-Agbada) petroleum system [14]. Fig. 1 shows the Niger Delta Map \& Base Map of the study area. 


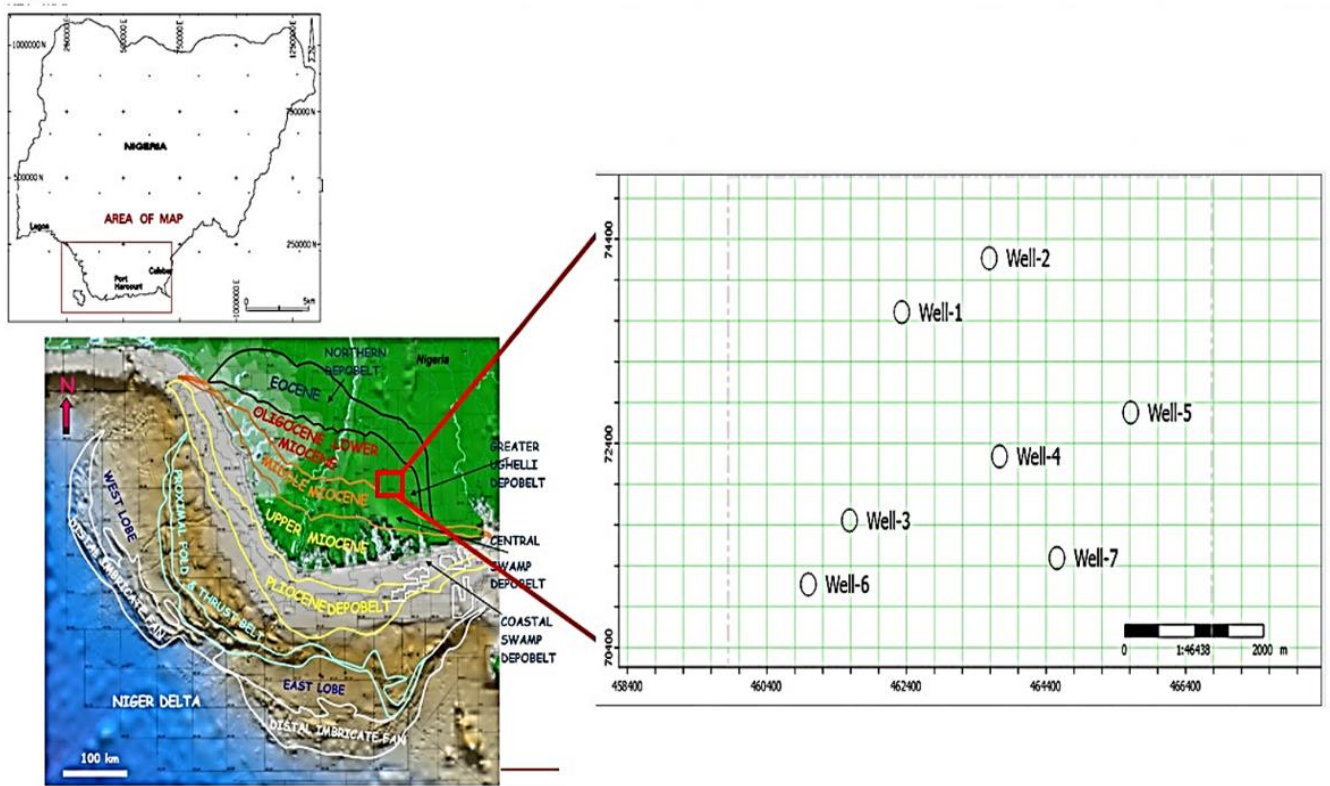

Figure 1: Location and Base Map of the Study Area

\section{METHOD AND MATERIALS}

Dataset from Seven (7) wireline logs are available in the field of study (Zeta). The logs consist of gamma ray, resistivity, density, sonic and caliper (Table 1 shows the Log Inventory of Available Wells in the Field). All the wells are vertical and most have a full suite of wireline logs over the target reservoir interval. The logs were loaded into the software and data conditioning (filtering) applied done. Using the de-spiking tool of the Hampson Russell Software, a median filter with an operator length of 3 was applied in order to cutoff the false effect caused by high frequency noise appearing as abnormal spikes in the log curves.

The methodology employed was detailed petrophysical evaluation to estimate reservoir properties and variation across the field was studied. First, the reservoirs are delineated and correlated across the field. Next, the various petrophysical parameters were calculated using already established models as follows:

A. Determination of Volume of Shale ( $\left.V_{\text {Shale }}\right)$

According to Larionov's [15], the volume of shale was estimated in the study using the relationship,

$$
V_{S h}=0.083\left(23.7 I_{G R}-1\right)
$$

Where,

$$
\begin{aligned}
& V_{S h}=\text { Shale percentage in the formation } \\
& I_{G R}=\text { Gamma Ray index }
\end{aligned}
$$

The gamma ray index was computed using the GR log response according to Schlumberger relationship as seen in Paul et. al. [16]:

$$
I_{G R}=\frac{G R_{\log }-G R_{\min }}{G R_{\max }-G R_{\min }}
$$

Where,

$$
\begin{aligned}
G R_{\text {log }} & =\text { Gamma ray reading from log } \\
G R_{\min } & =\text { Minimum gamma ray reading } \\
G R_{\max } & =\text { Maximum gamma ray reading }
\end{aligned}
$$

B. Determination of Total Porosity $\left(\Phi_{T}\right)$

Porosity was determined from the density $\log s$ as described by Wyllie et. al. [17],

$$
\Phi_{T}=\frac{\rho_{m a}-\rho_{b}}{\rho_{m a}-\rho_{f l}}
$$

Where,

$$
\begin{aligned}
& \rho_{m a}= \begin{array}{l}
\text { Matrix density }\left(2.69 \mathrm{gcm}^{-3},\right. \text { Density of } \\
\text { sandstone) }
\end{array} \\
& \rho_{b}=\begin{array}{l}
\text { Formation bulk density from density log (in } \\
\left.\mathrm{gcm}^{-3}\right)
\end{array} \\
& \rho_{f l}=\begin{array}{l}
\text { Fluid density }\left(0.87 \mathrm{gcm}^{-3},\right. \text { Density of oil } \\
\text { contained in the drilling mud) }
\end{array}
\end{aligned}
$$

C. Estimation of Effective Porosity ( $\left.\Phi_{\text {eff }}\right)$

According to Dresser [18], effective porosity the delineated reservoirs of interest was estimated as

$$
\Phi_{\text {eff }}=\Phi_{T}-\left(\Phi_{S h} \times V_{S h}\right)
$$

Where,

$$
\Phi_{S h}=\text { Log reading in a shale zone }
$$

D. Determination of Water/Hydrocarbon Saturation

The formation factor was determined using Archie's relationship,

$$
F=\frac{a}{\Phi_{T}^{m}}
$$

Where,

$$
\begin{aligned}
F & =\text { Formation Factor } \\
a & =\text { Tortuosity factor taken to be } 0.62 \\
m & =\text { Cementation factor which is } 2 \text { for sands }
\end{aligned}
$$

The water saturation for the uninvaded zone was determined using the Archie's [19] equation:

$$
S_{w}=\sqrt{\frac{R_{o}}{R_{T}}}
$$

Where,

$S_{w}=$ Water saturation of the uninvaded zone

$R_{O}=$ Resistivity of formation at $100 \%$ water saturation

$R_{T}=$ True resistivity of the formation

Hydrocarbon saturation, $S_{h}$, is given as 


$$
\begin{gathered}
S_{h}=\left(100-S_{w}\right) \% \\
S_{h}=1-S_{w}(\text { In Fraction })
\end{gathered}
$$

E. Determination of Permeability

Using the Wyllie and Rose [20] method, permeability (k) was estimated for the delineated reservoirs of interest such that,

$$
\begin{gathered}
K=\left(\frac{250 \times \Phi_{T}}{S_{\text {wirr }}}\right)^{2} \\
S_{\text {wirr }}=\sqrt{\frac{F}{2000}}
\end{gathered}
$$

Where,

$S_{\text {wirr }}=$ Irreducible water saturation

F. Determination of Net-to-Gross Thickness

The Net-to-Gross $(\mathrm{h} / \mathrm{H})$ Reservoir thickness is given as:

$$
h / H=\frac{H-h_{\text {Shale }}}{H}
$$

\begin{tabular}{|c|c|c|c|c|c|c|c|c|}
\hline \multicolumn{2}{|c|}{ Well Information } & Well 1 & Well 2 & Well 3 & Well 4 & Well 5 & Well 6 & Well 7 \\
\hline \multicolumn{2}{|c|}{ Well Header } & Yes & Yes & Yes & Yes & Yes & Yes & Yes \\
\hline \multicolumn{2}{|c|}{ Well Reservoir Tops } & Yes & Yes & Yes & Yes & Yes & Yes & Yes \\
\hline \multicolumn{2}{|c|}{ Well Deviation Sets } & No & No & No & No & No & No & No \\
\hline \multicolumn{2}{|c|}{ Well Checkshot } & No & No & Yes & No & Yes & No & No \\
\hline \multirow{6}{*}{$\begin{array}{l}0 \\
0 \\
0 \\
9 \\
3 \\
3 \\
3 \\
3\end{array}$} & GR & Yes & Yes & Yes & Yes & Yes & Yes & Yes \\
\hline & Sonic & Yes & Yes & Yes & No & Yes & Yes & No \\
\hline & Shear & Yes & No & No & No & Yes & No & No \\
\hline & Restiv. & Yes & Yes & Yes & Yes & Yes & Yes & Yes \\
\hline & Density & Yes & Yes & Yes & Yes & Yes & Yes & Yes \\
\hline & Calliper & Yes & Yes & Yes & Yes & Yes & Yes & Yes \\
\hline
\end{tabular}

Where,

$$
\begin{aligned}
H & =\text { Gross reservoir thickness } \\
h & =\text { Net reservoir thickness } \\
h_{\text {Shale }} & =\text { Shale thickness }
\end{aligned}
$$

Table 1: Well Log Inventory of Available Wells in the Field

\section{RESUlt AND Discussion}

\section{A. Reservoir Delineation and Well Correlation}

A total of twenty-one possible hydrocarbon-bearing zones (Sand A, Sand B \& Sand C) across seven wells (Wells 1 to 7) were delineated using combination of gamma ray and resistivity logs. The tops, bases and thicknesses of the three identified reservoirs are listed in Table 1. The wells display a shale/sand/shale arrangement which is descriptive of the Niger Delta formation. Low gamma ray and high resistivities are sand lithologies. Shale lithologies were defined by the high gamma ray value. Gamma ray logs accounts for the degree of radioactivity of rocks in the well which are connected to clay mineral, oil source rock, organic matter and shale in reservoir rock
(Schlumberger, 1972). Shale-free sandstones normally have low radioactive concentrations representing relatively low gamma ray response. Resistivity is the property of a material or substance to resist the flow of electric current (Schlumberger, 1972). The deep resistivity log response against hydrocarbon-bearing zones as seen from the reservoirs were relatively high.

Well correlation which provides a knowledge of the general stratigraphy of the study field (Fig. 2). Twelve sand bodies marked reservoir Sand A to Sand C were correlated across the seven wells in the field. This analysis shows that each of the sand units extends through the field, varies in thickness and some units occurring at greater depth than their adjacent unit which is probably an indication of faulting.

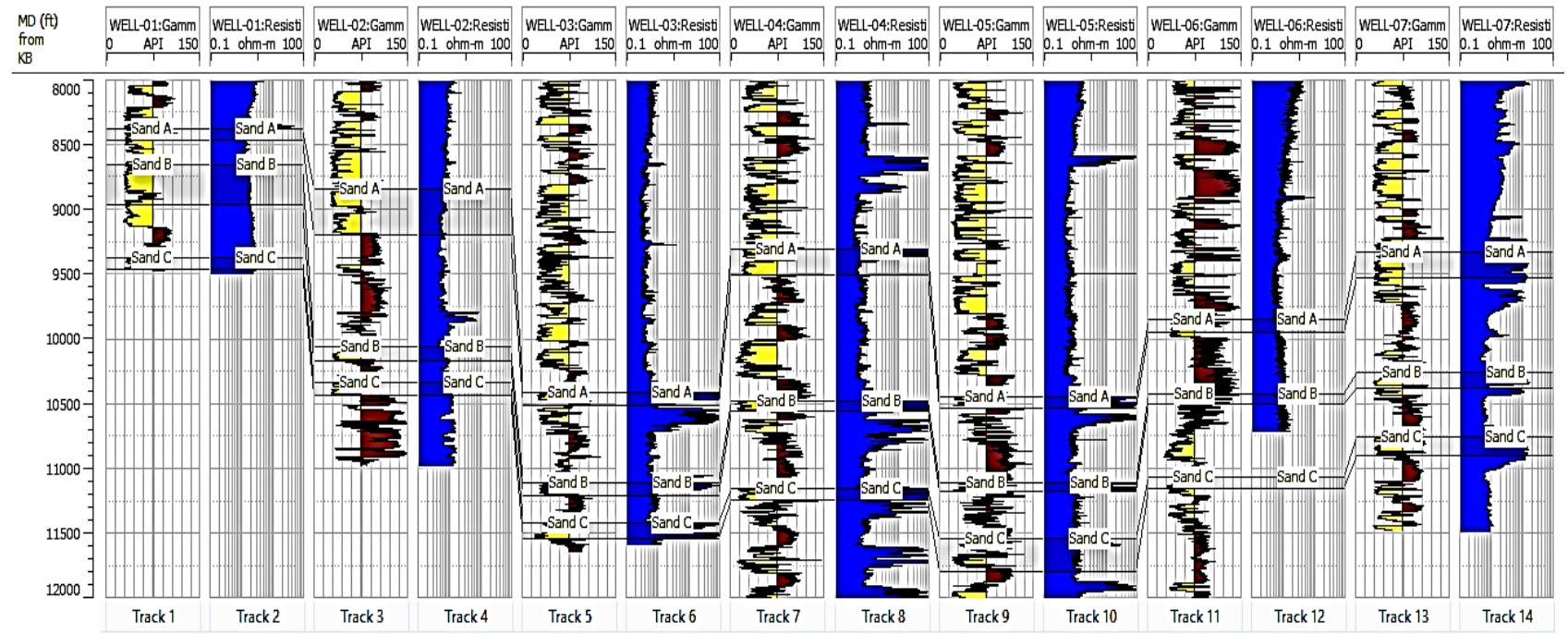

Figure 2: Well section window showing the correlation panel for all the sand bodies identified on well $\log$ 
Table 2: Reservoirs of interests for Well 1 to 7 for Sand A, Sand B \& Sand C.

\begin{tabular}{|c|c|c|c|c|}
\hline Well & $\begin{array}{l}\text { Reservoi } \\
\text { r Name }\end{array}$ & $\begin{array}{l}\text { Top } \\
\text { MD } \\
\text { (ft) }\end{array}$ & $\begin{array}{l}\text { Base } \\
\text { MD } \\
\text { (ft) }\end{array}$ & $\begin{array}{c}\text { Thicknes } \\
\text { s } \\
\text { (ft) }\end{array}$ \\
\hline \multirow{3}{*}{$\begin{array}{l}\text { WELL- } \\
01\end{array}$} & Sand A & 8329 & 8411 & 82 \\
\hline & Sand B & 8605 & 8911 & 306 \\
\hline & Sand C & 9321 & 9414 & 93 \\
\hline \multirow{3}{*}{$\begin{array}{l}\text { WELL- } \\
02\end{array}$} & Sand A & 8794 & 9144 & 350 \\
\hline & Sand B & 10013 & 10119 & 106 \\
\hline & Sand C & 10288 & 10392 & 104 \\
\hline \multirow{3}{*}{$\begin{array}{l}\text { WELL- } \\
03\end{array}$} & Sand A & 10364.7 & 10465 & 100.3 \\
\hline & Sand B & 11064 & 11168 & 104 \\
\hline & Sand C & 11374 & 11493 & 119 \\
\hline \multirow{3}{*}{$\begin{array}{l}\text { WELL- } \\
04\end{array}$} & Sand A & 9250 & 9446 & 196 \\
\hline & Sand B & 10425 & 10507 & 82 \\
\hline & Sand C & 11107 & 11189 & 82 \\
\hline \multirow{3}{*}{$\begin{array}{l}\text { WELL- } \\
05\end{array}$} & Sand A & 10399.4 & 10487 & 87.6 \\
\hline & Sand B & 11063 & 11126 & 63 \\
\hline & Sand C & 11500 & 11750 & 250 \\
\hline \multirow{3}{*}{$\begin{array}{l}\text { WELL- } \\
06\end{array}$} & Sand A & 9854.97 & 9946 & 91.03 \\
\hline & Sand B & 10431 & 10509 & 78 \\
\hline & Sand C & 11073 & 11160 & 87 \\
\hline \multirow{3}{*}{$\begin{array}{l}\text { WELL- } \\
07\end{array}$} & Sand A & 9326 & 9529 & 203 \\
\hline & Sand B & 10256 & 10379 & 123 \\
\hline & Sand C & 10764 & 10906 & 142 \\
\hline
\end{tabular}

B. Petrophysical Evaluation for Three Reservoir Intervals (Sand A, Sand B \& Sand $C$ )

i. Sand $A$

Table 3 shows the summary of the average petrophysical measures estimated for Sand A reservoir correlated across Well 1 to 7 . The volume of shale was calculated from gamma ray index and the values range from $7.50 \%$ to $41.33 \%$ indicating that the fraction of shale in the reservoirs is quite low. This means the reservoir has a large volume of sand deposit than shale, therefore, possibly saturated with hydrocarbon according to Essien [21]. The reservoirs total porosity was estimated from density log (RHOB) using porosity formula and these values ranges from 0.26 to 0.31 indicating a very good reservoir quality and reflecting probably well sorted coarse grained sandstone reservoirs with minimal cementation [22, 23]. The permeability of the reservoir units' range was from 284.45 to $2291.89 \mathrm{mD}$. This implies that the permeability varies from very good to excellent and suggests that these could be reservoir horizon with high hydrocarbon exploration potential [24]. The hydrocarbon saturation of the reservoirs ranges from 52.74 to 71.00 indicating that the proportion of void spaces occupied by water is low, which could consequently be indicative of high hydrocarbon saturation and high hydrocarbon production. The net-to-gross ranges from 0.46 to 0.84 . These results imply that the reservoir is highly porous and permeable. It also contains high hydrocarbons that is very viable for production.

\section{ii. Sand B}

Table 4 shows the summary of the average petrophysical evaluation for Sand B reservoir correlated across Well 1 to 7. Average volume of shale values ranges from 11.97 to $55.88 \%$. Low volume of shale signifies that the fraction of shale in the reservoirs is quite low, which means large volume of sand deposit than shale. Porosity values ranges from 0.17 to 0.27 indicating a very good reservoir quality [22, 25]. The permeability of the reservoir units' range was from 89.92 to $1010.16 \mathrm{mD}$. This implies that the permeability varies from very good to excellent. The water saturation of the reservoirs' ranges from 0.20 to 0.73 . High values of water saturation were observed in Well 2. This implies that those some parts of this reservoir rock contain low hydrocarbon saturation and potentially low hydrocarbon production. The netto-gross ranges from 0.61 to 0.82 .

iii. Sand $C$

Table 5 shows the summary of the average petrophysical evaluation for Sand C reservoir correlated across Well 1 to 7 . Average volume of shale values ranges 23.30 to $34.33 \%$. Low volume of shale signifies that the fraction of shale in the reservoirs is quite low, which means large volume of sand deposit than shale. Porosity values ranges from 0.15 to 0.25 indicating a very good reservoir quality. The permeability of the reservoir units' range was from 260.58 to $2552.67 \mathrm{mD}$. This implies that the permeability varies from very good to excellent $[22,25]$. The hydrocarbon saturation of the reservoirs ranges from 0.34 to 0.80 indicating that the proportion of void spaces occupied by water is low but high in Well 1. Well 1 contains little concentration of hydrocarbons. However, the other wells in this reservoir have high hydrocarbon saturation and high hydrocarbon production. The net-to-gross ranges from 0.34 to 0.68 .

Table 3: Petrophysical evaluation for Sand A reservoir correlated across Well 1 to Well 7

\begin{tabular}{|c|c|c|c|c|c|c|c|c|c|c|c|c|c|c|c|}
\hline & \multirow{2}{*}{$\begin{array}{c}\text { Unit } \\
\text { (ft) }\end{array}$} & \multicolumn{2}{|c|}{ Well 1} & \multicolumn{2}{|c|}{ Well 2} & \multicolumn{2}{|c|}{ Well 3} & \multicolumn{2}{|c|}{ Well 4} & \multicolumn{2}{|c|}{ Well 5} & \multicolumn{2}{|c|}{ Well 6} & \multicolumn{2}{|c|}{ Well 7} \\
\hline & & Top & Base & Top & Base & Top & Base & Top & Base & Top & Top & Base & Top & Base & Top \\
\hline $\begin{array}{l}\text { Gross } \\
\text { Thickness }\end{array}$ & $\mathrm{ft}$ & \multicolumn{2}{|c|}{82} & \multicolumn{2}{|c|}{350} & \multicolumn{2}{|c|}{100.3} & \multicolumn{2}{|c|}{196} & \multicolumn{2}{|c|}{87.6} & \multicolumn{2}{|c|}{91.03} & \multicolumn{2}{|c|}{203} \\
\hline Shale Volume & $\%$ & \multicolumn{2}{|c|}{25.95} & \multicolumn{2}{|c|}{7.50} & \multicolumn{2}{|c|}{24.39} & \multicolumn{2}{|c|}{17.60} & \multicolumn{2}{|c|}{41.33} & \multicolumn{2}{|c|}{33.25} & \multicolumn{2}{|c|}{15.10} \\
\hline Net Thickness & $\mathrm{ft}$ & \multicolumn{2}{|c|}{45.72} & \multicolumn{2}{|c|}{335.92} & \multicolumn{2}{|c|}{66.70} & \multicolumn{2}{|c|}{142.64} & \multicolumn{2}{|c|}{25.74} & \multicolumn{2}{|c|}{46.80} & \multicolumn{2}{|c|}{157.11} \\
\hline Net-to-Gross & Frac & \multicolumn{2}{|c|}{0.56} & \multicolumn{2}{|c|}{0.96} & \multicolumn{2}{|c|}{0.67} & \multicolumn{2}{|c|}{0.73} & \multicolumn{2}{|c|}{0.29} & \multicolumn{2}{|c|}{0.51} & \multicolumn{2}{|c|}{0.77} \\
\hline Eff. Porosity & Frac & & & 0. & & 0. & & 0. & & 0 . & & 0.1 & & & 27 \\
\hline Water Sat & Frac & & & 0 . & & 0 . & & 0 . & & 0 . & & 0.4 & & & 16 \\
\hline
\end{tabular}




\begin{tabular}{|l|l|c|c|c|c|c|c|c|}
\hline HC Sat & Frac & 0.65 & 0.46 & 0.74 & 0.66 & 0.69 & 0.51 & 0.84 \\
\hline Permeability & $\mathrm{mD}$ & 1701.00 & 395.54 & 1340.15 & 849.27 & 994.71 & 284.45 & 2291.89 \\
\hline
\end{tabular}

Table 4: Petrophysical evaluation for Sand B reservoir correlated across Well 1 to Well 7

\begin{tabular}{|c|c|c|c|c|c|c|c|c|c|c|c|c|c|c|c|}
\hline & \multirow{3}{*}{$\begin{array}{l}\text { Unit } \\
\text { (ft) }\end{array}$} & \multicolumn{2}{|c|}{ Well 1} & \multicolumn{2}{|c|}{ Well 2} & \multicolumn{2}{|c|}{ Well 3} & \multicolumn{2}{|c|}{ Well 4} & \multicolumn{2}{|c|}{ Well 5} & \multicolumn{2}{|c|}{ Well 6} & \multicolumn{2}{|c|}{ Well 7} \\
\hline & & Top & Base & Top & Base & Top & Base & Top & Base & Top & Top & Base & Top & Base & Top \\
\hline & & 8605 & 8911 & 10013 & 10119 & 11064 & 11168 & 10425 & 10507 & 11063 & 11126 & 10431 & 10509 & 10256 & 10379 \\
\hline $\begin{array}{l}\text { Gross } \\
\text { Thickness }\end{array}$ & $\mathrm{Ft}$ & \multicolumn{2}{|c|}{306} & \multicolumn{2}{|c|}{106} & \multicolumn{2}{|c|}{104} & \multicolumn{2}{|c|}{82} & \multicolumn{2}{|c|}{63} & \multicolumn{2}{|c|}{78} & \multicolumn{2}{|c|}{123} \\
\hline Shale Volume & $\%$ & \multicolumn{2}{|c|}{11.97} & \multicolumn{2}{|c|}{40.02} & \multicolumn{2}{|c|}{31.52} & \multicolumn{2}{|c|}{46.28} & \multicolumn{2}{|c|}{55.88} & \multicolumn{2}{|c|}{41.36} & \multicolumn{2}{|c|}{37.10} \\
\hline Net Thickness & $\mathrm{Ft}$ & \multicolumn{2}{|c|}{249.09} & \multicolumn{2}{|c|}{41.31} & \multicolumn{2}{|c|}{43.29} & \multicolumn{2}{|c|}{22.86} & \multicolumn{2}{|c|}{10.42} & \multicolumn{2}{|c|}{19.76} & \multicolumn{2}{|c|}{14.87} \\
\hline Net-to-Gross & Frac & \multicolumn{2}{|c|}{0.81} & \multicolumn{2}{|c|}{0.39} & \multicolumn{2}{|c|}{0.42} & \multicolumn{2}{|c|}{0.28} & \multicolumn{2}{|c|}{0.17} & \multicolumn{2}{|c|}{0.48} & & .40 \\
\hline Total Porosity & Frac & & & & 17 & 0 . & 27 & & 20 & & .18 & 0. & 24 & & 27 \\
\hline Eff. Porosity & Frac & & & & 12 & 0. & 19 & & 13 & & .09 & 0 . & 15 & & .21 \\
\hline Water Sat & Frac & & 51 & & 73 & 0. & 20 & & 49 & & .55 & 0. & 42 & & .44 \\
\hline HC Sat & Frac & & 49 & & 27 & 0. & 80 & & 51 & & .45 & 0. & 58 & & .56 \\
\hline Permeability & $\mathrm{mD}$ & & .16 & & 2.02 & 996 & 69 & 126 & 4.20 & & 7.17 & & .92 & & 0.16 \\
\hline
\end{tabular}

Table 5: Petrophysical evaluation for Sand C reservoir correlated across Well 1 to Well 7

\begin{tabular}{|c|c|c|c|c|c|c|c|c|c|c|c|c|c|c|c|}
\hline & \multirow{3}{*}{ Unit } & \multicolumn{2}{|c|}{ Well 1} & \multicolumn{2}{|c|}{ Well 2} & \multicolumn{2}{|c|}{ Well 3} & \multicolumn{2}{|c|}{ Well 4} & \multicolumn{2}{|c|}{ Well 5} & \multicolumn{2}{|c|}{ Well 6} & \multicolumn{2}{|c|}{ Well 7} \\
\hline & & Top & Base & Top & Base & Top & Base & Top & Base & Top & Base & Top & Base & Top & Base \\
\hline & & 9321 & 9414 & 10288 & 10392 & 11374 & 11493 & 11107 & 10507 & 9321 & 9414 & 10288 & 10392 & 11374 & 11493 \\
\hline Gross Thickness & $\mathrm{Ft}$ & \multicolumn{2}{|c|}{93} & \multicolumn{2}{|c|}{104} & \multicolumn{2}{|c|}{119} & \multicolumn{2}{|c|}{82} & \multicolumn{2}{|c|}{250} & \multicolumn{2}{|c|}{87} & \multicolumn{2}{|c|}{142} \\
\hline Shale Volume & $\%$ & \multicolumn{2}{|c|}{33.66} & \multicolumn{2}{|c|}{23.30} & \multicolumn{2}{|c|}{28.95} & \multicolumn{2}{|c|}{33.29} & \multicolumn{2}{|c|}{33.78} & \multicolumn{2}{|c|}{34.33} & \multicolumn{2}{|c|}{26.28} \\
\hline Net Thickness & $\mathrm{Ft}$ & \multirow{2}{*}{\multicolumn{2}{|c|}{$\frac{42.78}{0.46}$}} & \multicolumn{2}{|c|}{70.72} & \multirow{2}{*}{\multicolumn{2}{|c|}{58.31}} & \multirow{2}{*}{\multicolumn{2}{|c|}{36.08}} & \multirow{2}{*}{\multicolumn{2}{|c|}{$\frac{117.5}{0.47}$}} & \multicolumn{2}{|c|}{29.58} & \multicolumn{2}{|c|}{85.2} \\
\hline Net-to-Gross & Frac & & & & 68 & & & & & & & & & & 60 \\
\hline Total Porosity & Frac & \multicolumn{2}{|c|}{0.19} & \multicolumn{2}{|c|}{0.22} & \multicolumn{2}{|c|}{0.28} & \multicolumn{2}{|c|}{0.30} & \multicolumn{2}{|c|}{0.20} & \multicolumn{2}{|c|}{ NIL } & & 32 \\
\hline Eff. Porosity & Frac & 0. & 15 & & 17 & & 20 & 0. & 21 & & 15 & & & & 25 \\
\hline Water Sat. & Frac & 0. & 66 & & 50 & & 27 & 0. & 25 & & 46 & & & & 20 \\
\hline HC Sat & Frac & 0. & 34 & & 50 & & 73 & 0 . & 75 & & 54 & & & & 80 \\
\hline Permeability & $\mathrm{mD}$ & 595 & .75 & & .58 & & 5.95 & 171 & 1.34 & & 02 & & & & 2.67 \\
\hline
\end{tabular}

\section{CONCLUSION}

This study was designed to predict petrophysical properties in a target oil field (the Zeta field in this case, located in the Niger Delta region of Nigeria). Estimates of porosity, permeability, water saturation, volume of shale etc. derived from log measurement were estimated for the study area. The following conclusions were arrived at.

i. Three (3) reservoir sands were delineated from the seven delineated well logs in the study area.

ii. Porosities tend to be lower in deeper and older (consolidated) formations, due to cementation and overburden pressure stress on the rock. The fractional values of porosities estimated within the study area ranged from 0.15 to 0.26 .

iii. The values of shale volume obtained for the study area ranged between $7.5 \%$ to $55.88 \%$.

iv. The fractional values of water saturation estimated in the three reservoirs of interest ranged between 0.16-0.73.

v. The permeability of the reservoir units estimated ranged from 89.92 to $2552.67 \mathrm{mD}$.

vi. The values of net-to-gross (NTG) ratio estimated for the study area ranged from 0.17 to 0.96 . vii. From these estimates, the reservoirs within the study area are potentially hydrocarbon bearing and could be viable for further exploratory activities.

\section{REFERENCES}

[1] Dandekar, A.Y., Petroleum reservoir rock and fluid properties. 2013: CRC press.

[2] Hilchie, D.W., Wireline: A history of the well logging and perforating business in the oil fields. 1990: DW Hilchie.

[3] Senosy, A.H., H.F. Ewida, H.A. Soliman, and M.O. Ebraheem, Petrophysical analysis of well logs data for identification and characterization of the main reservoir of Al Baraka Oil Field, Komombo Basin, Upper Egypt. SN Applied Sciences, 2020. 2(7): p. 1-14.

[4] Asquith, G.B., D. Krygowski, and C.R. Gibson, Basic well log analysis. Vol 16. 2004: American association of petroleum geologists Tulsa, OK.

[5] Speight, J.G., Natural Gas: A Basic Handbook. 2018: Gulf Professional Publishing.

[6] Amigun, J.O. and O.A. Odole, Petrophysical properties evaluation for reservoir characterisation of Seyi oil field (Niger-Delta). International Journal of Innovation and Applied Studies, 2013. 3(3): p. 756-773.

[7] Ajisafe, Y. and B. Ako, 3-D seismic attributes for reservoir characterization of "Y" field Niger Delta, Nigeria. Journal of Applied Geology and Geophysics, 2013. 1(2): p. 23-31.

[8] Richardson, A.-A.M., Well correlation and Petrophysical analysis, a case study of "Rickie" field onshore Niger Delta. The International Journal of Engineering and Science, 2013. 2(12): p. 94-99. 
[9] Eze, M., A. Mode, and C. Ugbor, Formation evaluation of X7 field in the Niger Delta: evidence from Petrophysical data. Niger Delta, Nigeria. Journal of Applied Geology and Geophysics, 2013. 1(4): p. 15-21.

[10] Edigbue, P., A. Komolafe, A. Adesida, and O. Itamuko, Hydrocarbon reservoir characterization of "Keke" field, Niger Delta using 3D seismic and petrophysical data. American Journal of Scientific and Industrial Research, 2014. 2(1): p. 043-052.

[11] Doust, H. and E. Omatsola, Niger delta. American Association of Petroleum Geologists Memoir, 1989. 48: p. 201-238.

[12] Tuttle, M.L., R.R. Charpentier, and M.E. Brownfield, The Niger Delta Petroleum System: Niger Delta Province, Nigeria, Cameroon, and Equatorial Guinea, Africa. 1999: US Department of the Interior, US Geological Survey.

[13] Reijers, T., S. Petters, and C. Nwajide, The Niger delta basin, in Sedimentary basins of the world. 1997, Elsevier. p. 151-172.

[14] Ekweozor, C. and E. Daukoru, Northern delta depobelt portion of the AkataAgbada petroleum system. Niger Delta, Nigeria, in, Magoon, LB, Dow, WG eds., The Petroleum System--From Source to Trap, AAPG Memoir, 1994. 60: p. 599-614.

[15] Larionov, V., Radiometry of boreholes. Nedra, Moscow, 1969. 127.

[16] Paul, S., E. Okwueze, and K. Udo, Petrophysical analysis of well logs for the estimation of oil reserves in Southern Niger Delta. International Journal of Advanced Geosciences, 2018. 6(1): p. 140-145.

[17] Wyllie, M., A. Gregory, and G. Gardner, An experimental investigation of factors affecting elastic wave velocities in porous media. Geophysics, 1958. 23(3): p. 459-493.

[18] Dresser, M. and M. Moses, Silver staining of synaptonemal complexes in surface spreads for light and electron microscopy. Experimental Cell Research, 1979. 121(2): p. 416-419.

[19] Archie, G.E.J., Introduction to petrophysics of reservoir rocks. AAPG bulletin, 1950. 34(5): p. 943-961.

[20] Wyllie, M. and W.D. Rose, Some theoretical considerations related to the quantitative evaluation of the physical characteristics of reservoir rock from electrical log data. Journal of Petroleum Technology, 1950. 2(04): p. $105-$ 118.

[21] Essien, U.E., Shale volume and porosity delineation of coast swamp depobelt in Niger Delta Region, Nigeria, Using Well Log. International Journal of Advanced Geosciences, 2019. 7(2): p. 142-146.
[22] Orji, C.S., E.D. Uko, and I. Tamunobereton-ari, Permeability-Porosity Trends In Cawc Reservoir Sands In The Niger Delta Nigeria, Using WellLog Data. Malaysian Journal of Geosciences, 2019. 3(2): p. 33-42.

[23] Ehrenberg, S.N., P.H. Nadeau, and Ø. Steen, A megascale view of reservoir quality in producing sandstones from the offshore Gulf of Mexico. AAPG bulletin, 2008. 92(2): p. 145-164.

[24] Epuh, E.E. and E.O. Joshua, Modeling of porosity and permeability for hydrocarbon Exploration: A case study of Gongola arm of the Upper Benue Trough. Journal of African Earth Sciences, 2020. 162: p. 103646.

[25] Ajdukiewicz, J.M. and R.H. Lander, Sandstone reservoir quality prediction The state of the art. AAPG bulletin, 2010. 94(8): p. 1083-1091.

\section{AUTHORS}

First Author - Mr. Prince S. Nwiyor, PhD (In View) Applied Geophysics, Ken Saro Wiwa Polytechnic, Bori, Rivers State, Nigeria.

Second Author - Prof. Etim D. Uko, PhD Applied Geophysics, Rivers State University, Port Harcourt, Rivers State Nigeria.

Third Author - Dr. Iyeneomie Tamunobereton-ari, PhD Applied Geophysics, Rivers State University, Port Harcourt, Rivers State Nigeria

Fourth Author - Dr. Arobo R. C. Amakiri, PhD Applied Geophysics, Rivers State University, Port Harcourt, Rivers State Nigeria.

Fifth Author - Dr. Onengiyeofori A. Davies, PhD Applied Geophysics, Rivers State University, Port Harcourt, Rivers State Nigeria.

Correspondence Author - Dr. Onengiyeofori A. Davies, davies.onengiyeofori@ust.edu.ng 